\title{
Evaluation of model-based seasonal streamflow and water allocation forecasts for the Elqui Valley, Chile
}

\author{
Justin Delorit $^{1}$, Edmundo Cristian Gonzalez Ortuya ${ }^{2}$, and Paul Block ${ }^{1}$ \\ ${ }^{1}$ Department of Civil and Environmental Engineering, University of Wisconsin-Madison, Madison, WI, USA \\ ${ }^{2}$ Department of Industrial and Civil Engineering, University of La Serena, La Serena, Chile \\ Correspondence to: Justin Delorit (delorit@wisc.edu)
}

Received: 2 February 2017 - Discussion started: 13 February 2017

Revised: 11 July 2017 - Accepted: 25 August 2017 - Published: 21 September 2017

\begin{abstract}
In many semi-arid regions, multisectoral demands often stress available water supplies. Such is the case in the Elqui River valley of northern Chile, which draws on a limited-capacity reservoir to allocate 25000 water rights. Delayed infrastructure investment forces water managers to address demand-based allocation strategies, particularly in dry years, which are realized through reductions in the volume associated with each water right. Skillful season-ahead streamflow forecasts have the potential to inform managers with an indication of future conditions to guide reservoir allocations. This work evaluates season-ahead statistical prediction models of October-January (growing season) streamflow at multiple lead times associated with manager and user decision points, and links predictions with a reservoir allocation tool. Skillful results (streamflow forecasts outperform climatology) are produced for short lead times (1 September: ranked probability skill score (RPSS) of 0.31 , categorical hit skill score of $61 \%$ ). At longer lead times, climatological skill exceeds forecast skill due to fewer observations of precipitation. However, coupling the 1 September statistical forecast model with a sea surface temperature phase and strength statistical model allows for equally skillful categorical streamflow forecasts to be produced for a 1 May lead, triggered for $60 \%$ of years (1950-2015), suggesting forecasts need not be strictly deterministic to be useful for water rights holders. An early (1 May) categorical indication of expected conditions is reinforced with a deterministic forecast (1 September) as more observations of local variables become available. The reservoir allocation model is skillful at the 1 September lead (categorical hit skill score of $53 \%$ ); skill improves to $79 \%$ when categorical allocation prediction certainty exceeds $80 \%$. This result implies that allocation
\end{abstract}

efficiency may improve when forecasts are integrated into reservoir decision frameworks. The methods applied here advance the understanding of the mechanisms and timing responsible for moisture transport to the Elqui Valley and provide a unique application of streamflow forecasting in the prediction of water right allocations.

\section{Introduction}

The sustainability of many water systems is challenged by current climate variability and may come under additional stress with changes in future climate and user demands. Concerns over increasing water scarcity have prompted progressive governments, institutions, water resource managers, and end users to adopt a wide variety of conservation policies, typically targeting supply augmentation or demand reduction at the basin or jurisdictional boundary scale (Tanaka et al., 2006). These decisions, which are ideally informed by a variety of models, are inherently uncertain across timescales, and produce numerous risks stemming from human activity and hydroclimatic variability/change (Narula and Lall, 2009). Advanced hydroclimatic information is often attractive to progressive water managers to support management and planning of water systems (Barsugli et al., 2012). At the seasonal scale, a skillful streamflow forecast may allow more efficient water allocation and predictable trade-offs between flows for energy, irrigation, municipalities, environmental services, etc. Such forecasts often provide the ability to prepare for anticipated conditions and not simply react to existing conditions, potentially reducing climate-related risks and offering opportunities (Helmuth et al., 2007). This may 
be especially informative in years with extreme conditions (floods, droughts). Further motivation stems from evidence that indicates addressing climate variability as part of water development is key for stabilizing and improving country economies (Brown and Lall, 2006).

While improvements in seasonal climate forecast skill and advocacy for integration into risk reduction strategies are well documented (Barnston et al., 1994; Block, 2011; Block et al., 2009; Dee et al., 2011; Hansen et al., 2004; Mason and Stephenson, 2008), demonstrated use of forecasts in current water allocation and policy strategies is limited (Barnston et al., 1994; Christensen et al., 2004; Hamlet et al., 2002; Sankarasubramanian et al., 2009; Stakhiv, 1998). This is partially attributable to the widespread use of static operational policies, which may be based on average streamflow or the drought of record and established with minimal to no accounting of uncertainty, thus limiting water system flexibility (You and Cai, 2008). Effectively translating emerging climate information into hydrology to support adaptable water resources decision-making, and ultimately policy, warrants further study.

The water system in the semi-arid Elqui Valley in north central Chile's region IV (Fig. 1) is contending with increasing levels of water stress and demand, coupled with insufficient investment in infrastructure, taxing its ability to sufficiently meet multiple water uses and maintain environmental quality. The valley footprint is relatively small $\left(<10000 \mathrm{~km}^{2}\right)$ but boasts elevation changes ranging from sea level in the west to nearly $5000 \mathrm{~m}$ in the east along the Andes in the span of less than $150 \mathrm{~km}$. The Atacama Desert lies just to the north. The valley is fed from a retreating glacier to serve its 600000 inhabitants and is very narrow, with vineyards and plantations covering the floor and increasingly moving up the valley sides; $43 \%$ of the region's surface land area is devoted to agricultural activities (Cepeda and Lopez-Cortes, 2004). Agricultural exports, particularly grapes, fruits, and avocados, dominate the valley's economy (Young et al., 2009) and are maintained by an extensive irrigation channel system latticing the valley, which diverts water from the main Elqui River. The Puclaro reservoir is the dominant storage facility in the valley, with a holding capacity of 200 million $\mathrm{m}^{3}$ (Fig. 1). The reservoir provides irrigation for about 21000 ha of the Elqui Valley, as well as small-scale hydropower (5.6 MW capacity), and it is a popular tourist destination, particularly for sailing and windsurfing (Cepeda and Lopez-Cortes, 2004).

Chile uses a market-oriented approach to water allocation, guided by its water code of 1981 (Donoso, 2006). The intent is to allow for optimal allocation and efficiency through a politically neutral mechanism via permanent trades or leasing (Olmstead, 2010; Wheeler et al., 2013). Rights are granted through the national water authority (Dirección General de Aguas, hereafter DGA), while supervision, reservoir management, and issuance of annual per right allocation is left to the privately held, local water authority, Junta de Vigi- lancia del Rio Elqui (JVRE). Water rights along the Elqui River are fully allocated, with 25000 total rights valued at $1 \mathrm{~L} \mathrm{~s}^{-1}$ each. In years with above-normal precipitation and snowpack, this value can be attained; however, near-normal and below-normal precipitation years typically require a reduction in per right allocation, on the order of $0.5 \mathrm{~L} \mathrm{~s}^{-1}$. Prolonged periods of drought (2009-2015) have resulted in allocations as low as $0.2 \mathrm{~L} \mathrm{~s}^{-1}$ (JVRE, personal communication, 2016) All water rights are of equal standing; no prioritization or junior/senior status exists. Thus, right holders above and below Puclaro are guaranteed equal per right; surplus supply cannot be allocated to users downstream of the reservoir once the annual per right allocation has been officially issued. Approximately $92 \%$ of water rights are held by farmers, with half of those held by a small minority engaged in large-scale viticulture. Municipalities and the mining industry share the balance of water rights. Meeting targets for renewable energy through hydropower, ecosystem services, specifically minimum instream flows, and reservoir storage are also important competing, non-consumptive, or non-water-right-holding priorities.

The decision framework driving water allocation and market activity in the valley is complex and involves many actors. For the water year October-September, the local water authority initially projects the annual per right allocation in the preceding May and officially sets it in September. Water rights holders (users) thus have two decision points, May and September, to evaluate their allocation and weigh the need to supplement through market activity (trade or lease). This setting serves as an impetus for developing a framework to advance streamflow and water allocation forecasts at those decision points to better guide decision-making across the valley.

\section{Elqui hydroclimate characteristics}

The Elqui Valley is one of the most sensitive areas to water variability in all of South America, given its dryland ecosystem nature, susceptible to even small changes in the water cycle (Santibañez et al. 1992; Kalthoff et al., 2006). The climate of the region is affected by three major factors that lead to its semi-arid nature: the southeast Pacific anticyclone, the cold Humboldt current along the Pacific coast, and the eastern longitudinal barrier created by the Andes Mountains (Kalthoff et al., 2002). The majority of precipitation is frontal in nature, falling in the austral winter (May-August, MJJA) as rain in the valley and snow in the mountains; this leaves the remaining months extremely dry (Fig. 2; Aceituno, 1988). Annual rainfall totals approach $90 \mathrm{~mm}$ on average and express a high degree of variability (Young et al., 2009). The El Niño-Southern Oscillation (ENSO) is well known to have a role in this variability, with positive precipitation anomalies during El Niño events, and below-normal precipitation mostly associated with La Niña conditions (Fig. 3; Aceituno, 1988; Falvey and Garreaud, 2007; Garreaud et al., 2009; 


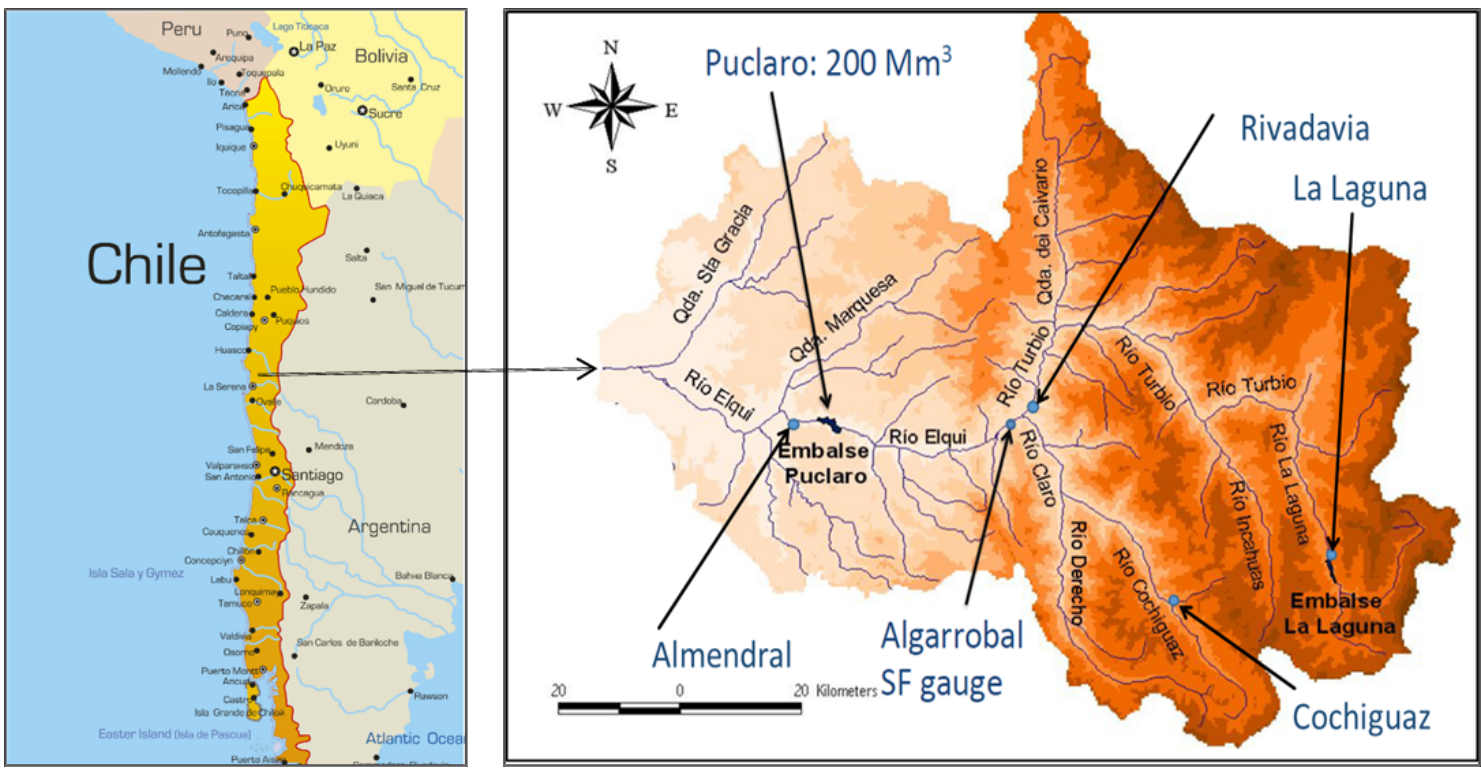

Figure 1. Location of Elqui River valley, Chile.

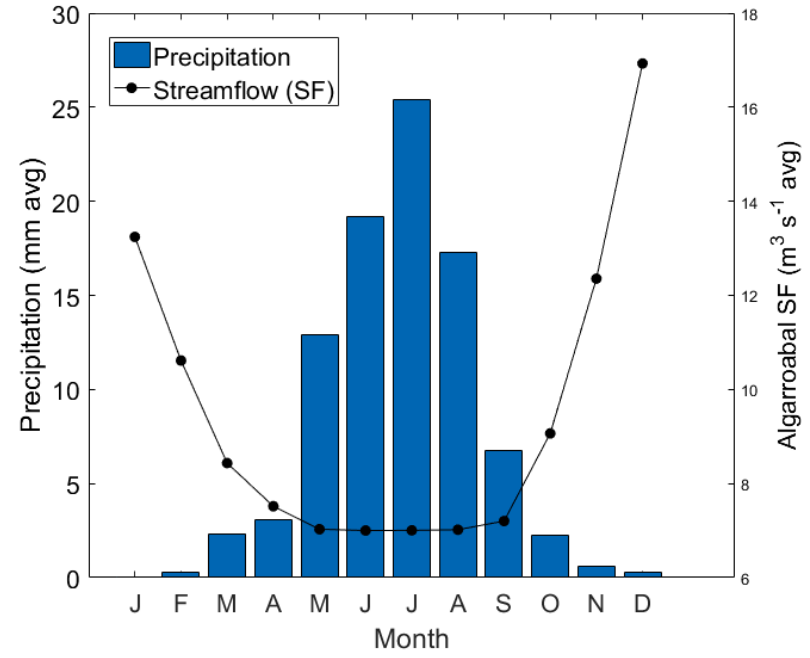

Figure 2. Annual cycle of average precipitation and streamflow (1950-2015).

Montecinos and Aceituno, 2003). For Vicuña, a city located in approximately the center of the valley, between 1950 and 2000, El Niño years produced average annual precipitation of $134 \mathrm{~mm}$, compared with $68 \mathrm{~mm}$ during La Niña years - a stark difference (Young et al., 2009).

The Elqui River is predominantly fed through snowmelt over the October-January (ONDJ) season, dictating the agricultural calendar. Historical rates of average streamflow over this season, however, indicate enormous interannual variability, ranging from 2.2 to $89 \mathrm{~m}^{3} \mathrm{~s}^{-1}$ at the Algarrobal station (Fig. 3; Santibañez et al., 1992), commonly considered as a surrogate for inflow to the Puclaro reservoir (Fig. 1). Rec-

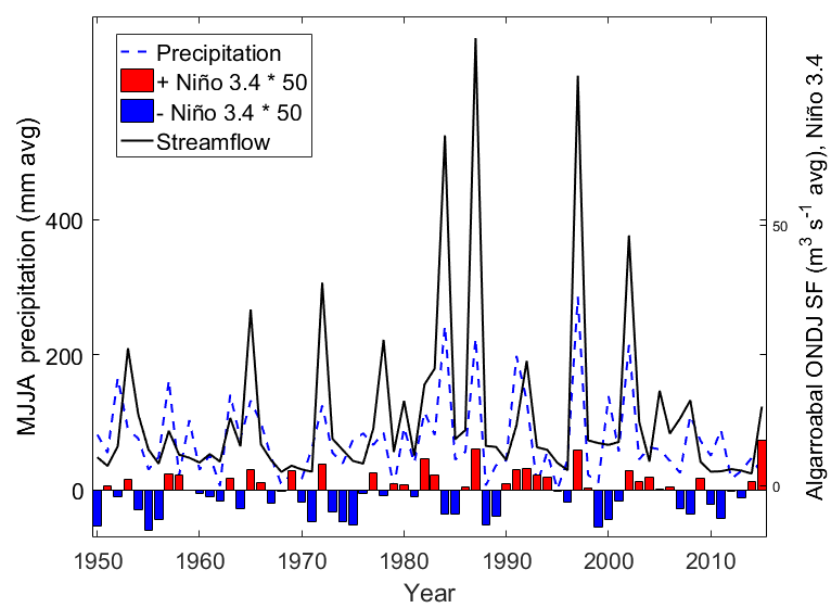

Figure 3. Total annual precipitation (dashed), streamflow (solid), and May-August Niño 3.4 sea surface temperature anomalies (bars).

ognizing that variable precipitation affects streamflow and subsequently water right allocation values, this research tests two hypotheses as a means of addressing the unique climate conditions of the Elqui Valley, which may be applied more broadly to water rights managed basins with limited water resources:

1. Skillful season-ahead streamflow forecasts can be produced for existing water right allocation decision points.

2. Skillful streamflow forecasts coupled with reservoir allocation decision tools can improve allocation efficiency. 


\section{Modeling framework and performance metrics}

Historically, water managers in the Elqui Valley have subjectively considered simple analog prediction models for ONDJ streamflow at Algarrobal, conditioned on the multivariate ENSO index (MEI), for allocation decisions and reservoir operations with limited success (JVRE, personal communication, 2016). Previous efforts to evaluate hydro-climate forecast skill for the Elqui River have considered leads consistent with the current water rights forecast structure: a preliminary 1 May allocation forecast and 1 September allocation issuance (Robertson et al., 2014; Verbist et al., 2010). Robertson et al. (2014) report a significant increase in forecast skill, comparing September to May, but suggest further investigation to more fully understand forecast skill with increasing lead time.

This recommendation is addressed by building a modeling framework to evaluate potential improvement in predicting ONDJ streamflow at multiple lead times, starting with a 1-month lead (1 September) and increasing at monthly intervals (i.e., 1 August, 1 July) to 1 May, when the first water allocation forecast is preliminarily issued. Both statistical and dynamical prediction approaches are explored. Subsequently, the ability to effectively predict water rights allocations is investigated by coupling streamflow predictions with a reservoir allocation model.

\subsection{Statistical streamflow prediction models}

\subsubsection{Data and predictor selection}

Statistical forecast methods rely on identification of spatiotemporal patterns in historical data (Chambers et al., 1971). A suite of potential predictor variables is evaluated which have been shown to influence either streamflow or precipitation, including global predictors: sea surface temperatures (SSTs), specifically in the Niño 1.2 and Niño 3.4 regions, sea level pressure (SLP), geopotential height, vector (also referred to as wind vectors), meridional winds, and the multivariate ENSO index (MEI) and local predictors: precipitation, snow water equivalent, and soil moisture (Montecinos and Aceituno, 2003; Wolter and Timlin, 1993). Global predictors, except MEI, are obtained at a $2.5 \times 2.5^{\circ}$ grid resolution from the National Oceanic and Atmospheric Administration's Climate Diagnostics Center (NOAA-CDC), which are based upon the National Centers for Environmental Prediction-National Center for Atmospheric Research (NCEP-NCAR) reanalysis data, available from 1949 to the present (Kalnay et al., 1996). Bimonthly MEI data are available from NOAA's Earth System Research Laboratory (ESRL) (Wolter and Timlin, 1993, 1998). Local predictors, valley-wide precipitation stations (daily, 1950present), and snow water equivalent (daily, 1950-2009) are each readily available through the Chilean DGA. One of DGA's primary functions as regulator of surface water re- sources for the Chilean Government is to collect, validate, and perform quality control of hydrologic measurements. Soil moisture data are obtained from NOAA's Climate Prediction Center's (CPC) global monthly soil moisture dataset, at $0.5 \times 0.5^{\circ}$ grid resolution, which is available from 1948 to the present (Huang et al., 1996; Kalnay et al., 1996; Saha et al., 2013). These variables can illustrate the mechanisms controlling moisture transport to the basin and subsequent interannual variability in streamflow, available through DGA at Algarrobal (monthly, 1948-present). For example, in the 10 lowest ONDJ streamflow years (dry), vector winds follow a weak, dissociated pattern in the preceding season, which indicates that moisture transport from the Pacific Ocean is inefficient (Fig. 4a). In the 10 highest ONDJ streamflow years (wet), vector winds are anomalously strong, and follow a coherent clockwise pattern off the coast of Chile, which suggests more efficient moisture transport is possible from the Pacific Ocean to the Elqui Valley (Fig. 4b).

Each variable is correlated with ONDJ streamflow at lead times consistent with those discussed above (Fig. 5; not all variables shown). Regions (gridded datasets) with statistically significant correlations in locations that have the potential to affect moisture transport (Table 1) are spatially averaged and retained for further evaluation. Spatial averaging is warranted when the first principal component (PC) and spatial average from the gridded variable region are highly correlated. If the first PC does not correlate well with the spatial average, the heterogeneity of the dataset is likely important, and adopting the spatial average as a predictor may be insufficient. For example, the spatial average of SSTs (Fig. 4c), a potentially significant predictor of streamflow for the Elqui River, correlates highly $(>0.9)$ with the first PC of the gridded SST data. This region of SSTs is closely aligned with the quintessential ENSO pattern in the equatorial Pacific Ocean and is evident when correlating the entire ONDJ streamflow record with SST anomalies in the preceding MJJA, which suggests ENSO, in general, plays some role in explaining streamflow variability within the Elqui Valley (Fig. 4c). Thus, we select the Niño 3.4 index as a potential predictor of streamflow, in lieu of the SST region initially identified (Fig. 4c), as it is well known, well understood, and well studied.

\subsubsection{Statistical modeling approaches}

Principal component regression (PCR) (Lins, 1985) is commonly applied in forecasting to decompose space-time fields, which reduces both dimensionality and multicollinearity of a set of variables. The result is a set of PCs representing the variance in the predictors. PCs with eigenvalues greater than 1 are retained following Kaiser's rule (Zwick and Velicer, 1986). A leave-one-out cross-validated hindcast is undertaken to produce a deterministic prediction of expected streamflow for each year (1950-2015) (Block and Rajagopalan, 2007). A prediction distribution is generated us- 

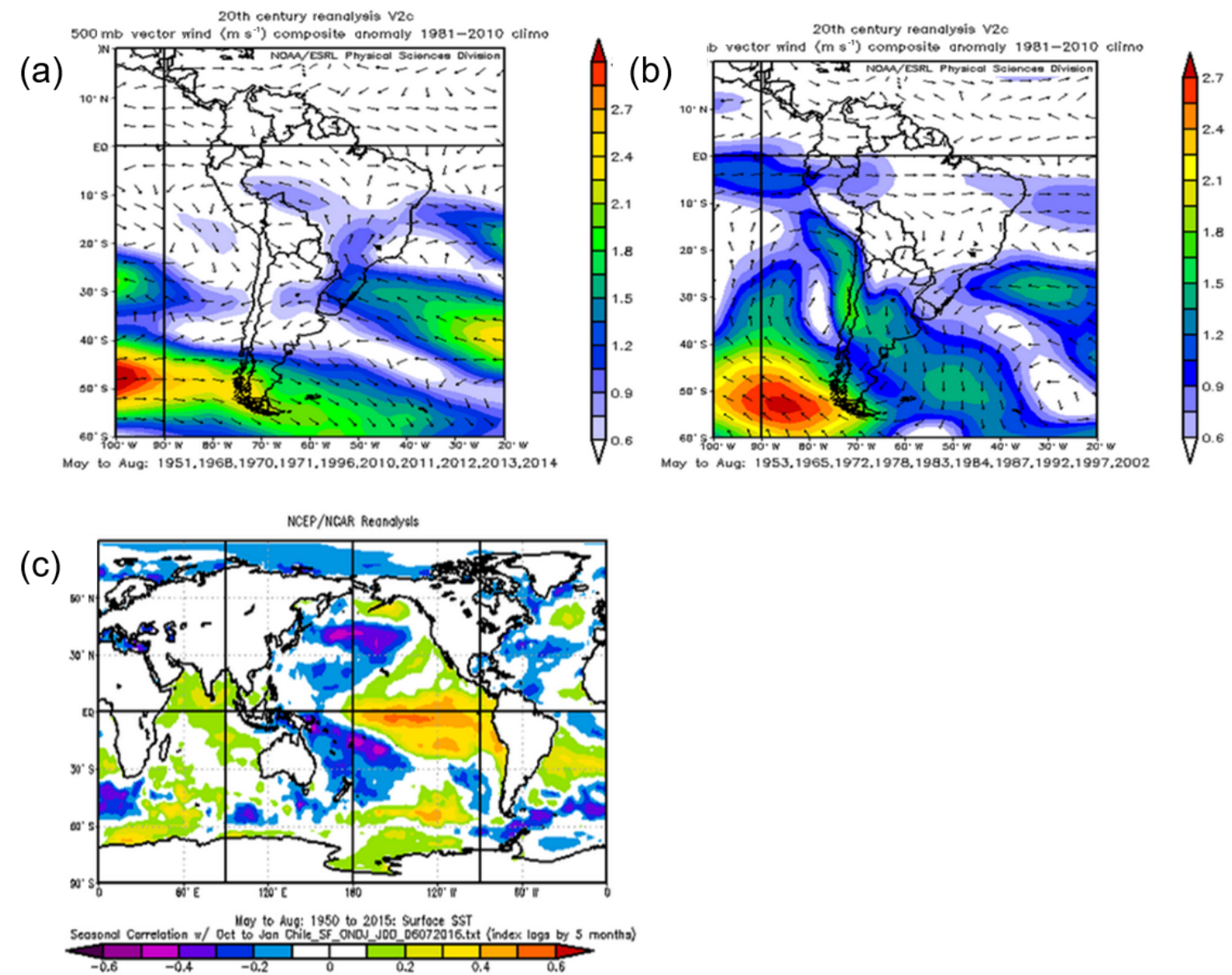

Figure 4. (a) Composite May-August (MJJA) vector wind anomaly preceding 10 lowest October-January (ONDJ) streamflow years. Panel (b) is the same as (a) for 10 highest ONDJ streamflow years; panel (c) indicates the correlation of MJJA sea surface temperature anomaly with ONDJ streamflow (1950-2015).

Table 1. List of potential predictors (bold predictors retained for statistical model).

\begin{tabular}{llr}
\hline Potential predictors & Location & $\begin{array}{r}\text { MJJA Pearson's } \\
\text { correlation with } \\
\text { ONDJ streamflow }\end{array}$ \\
\hline Lrecipitation & Local & \\
Soil moisture & 18 stations (valley wide) & +0.80 \\
Snow water equivalent & $29-30^{\circ} \mathrm{S}, 70-71^{\circ} \mathrm{W}$ & +0.55 \\
& One station (La Laguna) & +0.68 \\
\hline Geopotential height (800 mbar) & Global & +0.43 \\
Meridional wind & $45-60^{\circ} \mathrm{S}, 100-120^{\circ} \mathrm{W}$ & +0.37 \\
Multivariate ENSO index & $0-5^{\circ} \mathrm{S}, 160-180^{\circ} \mathrm{W}$ & +0.35 \\
Sea level pressure & Tropical Pacific anomaly & +0.22 \\
Sea surface temperatures (Niño 1.2) & $60-70^{\circ} \mathrm{S}, 100-120^{\circ} \mathrm{W}$ & +0.40 \\
Sea surface temperatures (Niño 3.4) & $0-10^{\circ} \mathrm{S}, 80-90^{\circ} \mathrm{W}$ & +0.49 \\
Vector wind & $5^{\circ} \mathrm{N}-5^{\circ} \mathrm{S}, 120-180^{\circ} \mathrm{W}$ & +0.47 \\
\hline
\end{tabular}



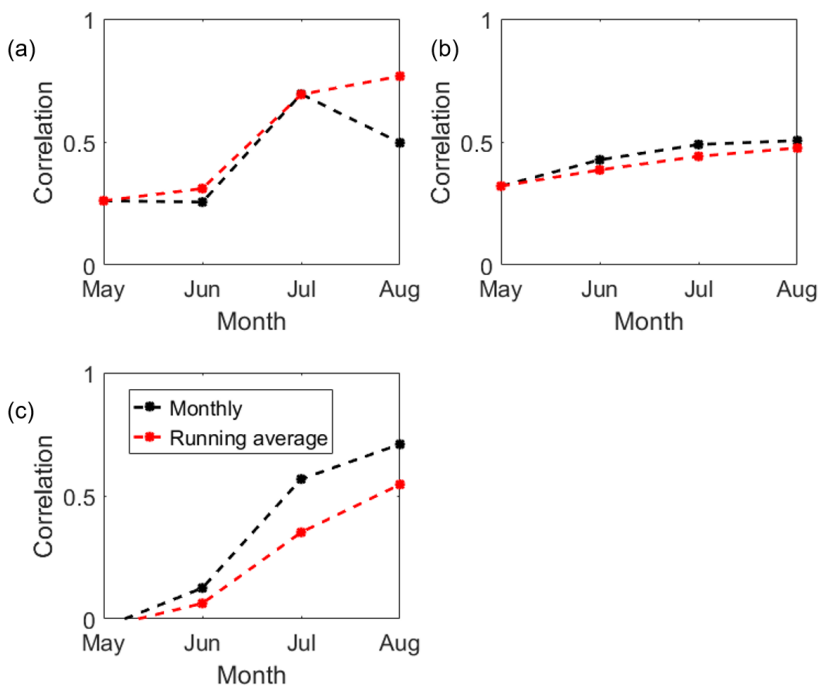

Figure 5. Temporal correlations of October-January streamflow and potential predictors: (a) precipitation, (b) Niño 3.4 sea surface temperatures, and (c) soil moisture.

ing prediction errors from the hindcast fit to a normal distribution with a mean of zero and added to the deterministic hindcast prediction. In this work, the median and upper 80th percentile hindcasted flows from the ranked outputs are analyzed to simulate potential risk aversion on the part of a reservoir manager. Hereafter, the statistical principal component regression approach is referred to as Stat-PCR.

In a separate statistical approach, a streamflow prediction model based on ENSO phase and strength (Stat-P\&S) is developed to provide categorical predictions of ONDJ streamflow. Using the Niño 3.4 index, NOAA has established weak $\left( \pm 0.25^{\circ} \mathrm{C}\right)$, moderate $\left( \pm 0.75^{\circ} \mathrm{C}\right)$, and strong $\left( \pm 1.0^{\circ} \mathrm{C}\right)$ categorical thresholds as a means of describing ENSO phase and strength (Trenberth et al., 2002). Recent research has illustrated a potential relationship between streamflow and ENSO phase and strength (Zimmerman et al., 2016). To qualify for prediction using Stat-P\&S, at least 1 month during a selected Niño 3.4 index window must be at least moderate in strength for a given phase, $\geq+0.75^{\circ} \mathrm{C}$ (El Niño) or $\leq-0.75^{\circ} \mathrm{C}$ (La Niña), and is categorically predicted as above-normal (A; highest $33 \%$ of long-term streamflow observations) or below-normal (B; lowest $33 \%$ of long-term streamflow observations) ONDJ streamflow, respectively. Window selection determines hindcast date and may fall prior to or during a phenomenon known as the spring barrier, when SSTs in equatorial Pacific generally reset, losing predictive strength (Webster and Hoyos, 2010). However, the effects of moderate and strong ENSO events have some tendency to persist (Balmaseda et al., 1995). When values from the Niño 3.4 index fail to exceed $\pm 0.5^{\circ} \mathrm{C}$, ONDJ streamflow is predicted to fall into the normal $(\mathrm{N}$; middle $33 \%$ of long-term streamflow observations) category. For years where the Niño 3.4 index values are $\left[+0.5,+0.75^{\circ} \mathrm{C}\right]$ or $\left[-0.5,-0.75^{\circ} \mathrm{C}\right]$, the Stat-P\&S model does not issue a forecast. For these ranges, neither the magnitude (not weak or moderate, as defined by NOAA) nor persistence of SST observations allows for production of skillful categorical streamflow forecasts. For years in which SSTs fall within these ranges at forecast leads prior to the spring barrier, strength and phase are subject to rapid transition, and categorical forecasts are typically not skillful.

\subsection{Dynamical climate model informed statistical streamflow prediction model}

\subsubsection{Data and predictor selection}

General circulation models (GCMs) and regional climate models (RCMs) are physically based, three-dimensional representations of gridded atmospheric, oceanic, and land surface processes, with typical spatial resolutions at or below $20 \mathrm{~km}$ resolution (Fowler and Ekström, 2009; Kendon et al., 2014). The relatively coarse resolution of GCMs often limits predictive ability for smaller-scale weather and climate phenomena, including precipitation (Bosilovich et al., 2008). However, considering the National American MultiModel Ensemble (NMME; Kirtman et al., 2013) suite of models, Verbist et al. (2010) demonstrate skillful prediction of north central Chile precipitation based on equatorial $\mathrm{Pa}$ cific SSTs in the ENSO region using NOAA's National Centers for Environmental Protection's (NCEP) Climate Forecast System version 2 GCM, available 1982-present (CFSv2; Kalnay et al., 1996). Considering both the findings of Verbist et al. (2010) and a strong Pearson's correlation coefficient between observed ONDJ streamflow and MJJA precipitation in the Elqui Valley (0.80), both precipitation and SSTs outputs from CFSv2 are retained for further evaluation. Specifically, the mean value of the 40-member ensemble of outputs for gridded precipitation $\left(29-30^{\circ} \mathrm{S}, 70-71^{\circ} \mathrm{W}\right)$ and the Niño 1.2 and 3.4 indices at leads between 1 January and 1 May is obtained and independently corrected using a statistical quantile mapping approach based on the cumulative distribution functions of both predicted and observed data (Maraun, 2013). For each lead, predicted values are replaced with values from the observed distribution, based on matching probabilities (Fig. 6; not all variables shown).

\subsubsection{Dynamic model informed statistical modeling approach}

The same PCR framework as in the Stat-PCR approach is applied using GCM-corrected precipitation and SSTs to predict ONDJ streamflow, referred to as the Stat-Dyn model. The Stat-Dyn model is meant to provide streamflow forecasts at extended leads, beyond what is possible with global and local observed data used to inform the Stat-PCR model. Local variables (e.g., precipitation, snow water equivalent and soil moisture) hold the most predictive strength as observations 

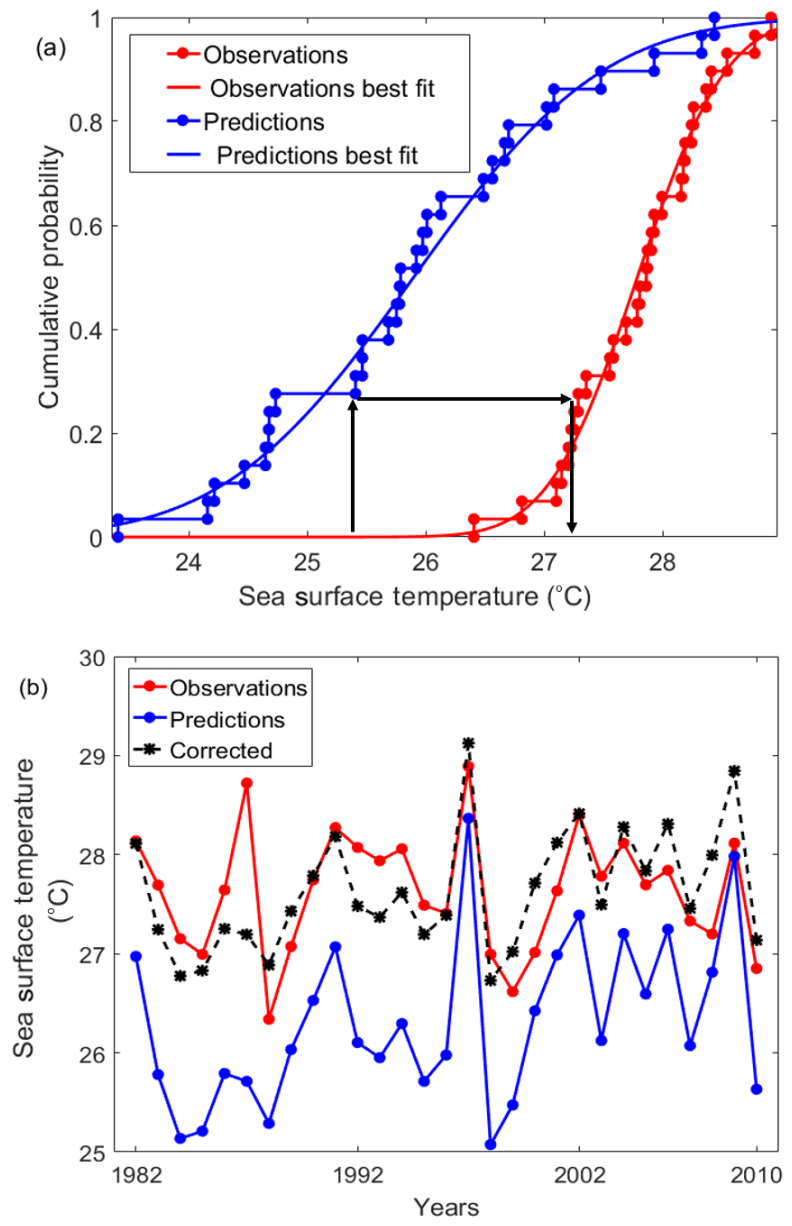

Figure 6. (a) Quantile mapping of predicted and observed NOAA NCEP CFSv2 Niño 3.4 sea surface temperature (SST) data; (b) observed, predicted, and statistically corrected NOAA NCEP CFSv2 Niño 3.4 SST data.

during the season of peak precipitation (May-August) and thus are only considered for the Stat-Dyn model for leads beginning on 1 June (Fig. 5a and c).

\subsection{Allocation forecast model}

Allocation, as issued annually by JVRE, and storage outcomes are hindcast in a cross-validated mode for the period of record (1950-2015) by coupling the streamflow prediction models to a simple reservoir balance model. As previously mentioned, if allocations are reduced to less than the defined maximum of $1 \mathrm{Ls}^{-1}$, all rights are reduced equivalently across rights holders, per Chile's water code. The Puclaro operating rules adopted here focus on the end-of-water-year (1 February) target reservoir volume, set at 100 million $\mathrm{m}^{3}$ (50\% capacity), which is consistent with current management practices for Puclaro reservoir. To account for annual deviation from the end-of-water-year storage target, allocation for ONDJ in year $i+1$ is adjusted by the difference be- tween end-of-water-year storage and the target in year $i$. Allocations may be larger if end-of-year storage exceeds target storage or smaller if there is a shortfall in end-of-year storage, as shown by Eq. (1), where

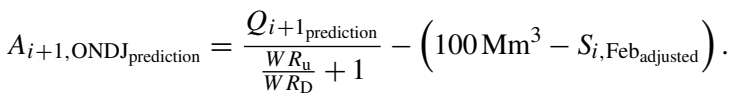

$A_{i+1, \text { ONDJ }_{\text {prediction }}}$ is the predicted allocation for ONDJ in year $i+1$. $Q_{i+1}$ prediction is the prediction of inflow in year $i+1$, with streamflow predictions for the non-ONDJ months constructed by regressing median ONDJ streamflow predictions onto February-September streamflow observations to produce predicted February-September streamflow. $\mathrm{WR}_{\mathrm{u}}$ and $\mathrm{WR}_{\mathrm{D}}$ are the number of water rights upstream and downstream of Puclaro, respectively, and $S_{i, \text { Feb }_{\text {adjusted }}}$ is the previous end-of-water-year adjusted storage volume, as shown by Eq. (2), where

$$
\begin{aligned}
S_{i, \mathrm{Feb}_{\text {adjusted }}} & =S_{i, \mathrm{Sep}_{\text {prediction }}} \\
& -\left(A_{i, \mathrm{ONDJ}_{\text {prediction }}}-A_{i, \mathrm{ONDJ}_{\text {observation }}}\right) .
\end{aligned}
$$

$S_{i, \text { Sep }_{\text {prediction }}}$ is the predicted storage at the time of ONDJ allocation issuance in year $i$, and $A_{i, \mathrm{ONDJ}_{\text {prediction }}}$ and

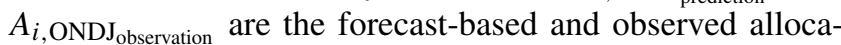
tion values in year $i$. This adjusted volume (predictions observations) accounts for storage deficit or surplus resulting from forecast-based allocations (forecasts never perfectly match observations) and allows for adjustment of allocation in the following year. Effectively, this accounts for the error in forecast-based allocations. The February storage shortfall or surplus is applied to the subsequent October-January per water right allocation value, as the storage target is nonbinding (can be violated by over- or under-allocation in the previous year), but consequential, in the allocation model. This functions as a mechanism to compensate for over- or under-allocation in the previous year.

Annual per water right allocations based on forecasts of 1 September reservoir volume, probabilistic inflow predictions, and end-of-water-year target reservoir volumes are reported as a probability of falling into three allocation categories: "moderate" $\left(\geq 0.5 \mathrm{~L} \mathrm{~s}^{-1}\right)$, "severe" $\left(0.5 \mathrm{~L} \mathrm{~s}^{-1}\right.$ $\left.0.25 \mathrm{~L} \mathrm{~s}^{-1}\right)$, and "extreme" $\left(<0.25 \mathrm{~L} \mathrm{~s}^{-1}\right)$. The selected categories are consistent with those used by the US Drought Monitor to describe similar ranges of industrial, social, and environmental impacts expected due to reduced access to water resources (Svoboda et al., 2002). Numerical thresholds assigned to the categorical boundaries align approximately with tercile values from the cumulative distribution of allocations derived from observed inflow and storage data, using the same reservoir operating rules as forecast-based allocations. Further, the breaks in categories closely follow decisions made by JVRE: a water right value of $0.5 \mathrm{~L} \mathrm{~s}^{-1}$ is not uncommon and approximately represents the lower bound in normal years (Hearne and Easter, 1995); during the 
most recent severe drought (2009-2014), water right values of $0.2 \mathrm{~L} \mathrm{~s}^{-1}$ were common (JVRE, personal communication, 2016)

\subsection{Performance metrics}

The performance of each cross-validated modeling approach is assessed deterministically (Pearson's correlation coefficient) and with a variety of categorical metrics to assess model skill in the prediction of specific categories (Regonda et al., 2006; Souza Filho and Lall, 2003). Two sets of categories are evaluated, as previously defined. The first is for streamflow hindcast prediction, with above- $(\mathrm{A})$, near- $(\mathrm{N})$, and below-normal (B) categories (ranges) based on a climatological distribution of observed ONDJ streamflow, each containing $33 \%$ of observations. The second is for per water right allocation hindcast prediction, applying the moderate, severe, and extreme categories, as previously defined and contingent on reservoir storage and forecast inflow. Categorical outputs are illustrated with contingency tables, comparing predicted vs. observed categorical occurrences. Model skill occurs when the cross-validated predicted conditions match or "hit" observed conditions, which describes the categorical performance of the entire forecast in comparison to observations. A "miss" results when the predicted value does not fall within the observed category. An "extreme miss" constitutes a categorical prediction missing an observation by two categories (model predicts above normal while below normal is observed, or vice versa).

Ranked probability skill score (RPSS) is a categorical measure of an ensemble prediction of each modeling approach compared to a reference forecast, in this case climatology (Saunders and Fletcher, 2004). The RPSS uses the ranked probability score (RPS), a measure of the square differences in the cumulative probability of a multi-categorical ensemble. The RPSS ranges from $-\infty$ to 1 ; values between 0 and 1 indicate greater skill than simply using climatology (i.e., basing prediction on long-term averages), while RPSS values less than 0 indicate that predictions are inferior to climatology. An RPSS value is generated for each of year of the hindcast using Eq. (3); the median RPSS value is reported.

$\mathrm{RPSS}=\frac{\overline{\mathrm{RPS}}-\overline{\mathrm{RPS}}_{\text {reference }}}{0-\overline{\mathrm{RPS}}_{\text {reference }}}=1-\frac{\overline{\mathrm{RPS}}}{\overline{\mathrm{RPS}}_{\text {reference }}}$

\section{Model performance}

\subsection{Statistical and dynamical streamflow prediction models}

For each cross-validated streamflow modeling hindcast assessment (Stat-PCR: 1950-2015; Stat-Dyn: 1982-present), a unique set of predictors and principal components are selected and evaluated with the categorical performance metrics (Pearson's correlation coefficient, "hit score", "extreme miss score", and RPSS; Table 2). As forecast lead increases, both hit score and RPSS decrease, while extreme miss score increases. This is not surprising, as less MJJA rainy season observations are available with increasing lead, which is consistent with decreased correlations between ONDJ streamflow and predictors (Fig. 5).

For the Stat-PCR set of models, the predictors for each lead time follow a similar pattern, utilizing soil moisture and SST from the month prior and precipitation for the 2 months prior to the forecast date (e.g., 1 September forecast uses August soil moisture and SST, and July-August precipitation). Snow water equivalent (SWE) is not retained as a predictor as its May-August correlation with October-January streamflow (Pearson's correlation coefficient of 0.68) is not as strong as the correlation between precipitation and streamflow for the same lead and arguably provides the same information to the model. As such, observations of precipitation are retained for the Stat-PCR model. The 1 September lead is promising; however, for longer leads this relationship does not necessarily hold. A 1 August lead is approximately equivalent to using climatology, and by 1 July it is worse. For the Stat-Dyn modeling approach, using the mean of CFSv2 ensemble forecasts for MJJA precipitation, Niño 3.4, and 1.2 SSTs at 1 June, 1 May, and 1 January lead times, respectively, produces low hit, high extreme miss, and negative RPSS scores (Table 2), confirming the challenges of predicting through the spring barrier.

The first principal component of the Stat-PCR 1 September forecast is highly correlated with SST in the Niño 3.4 region (0.88), which confirms that streamflow, and therefore precipitation in the Elqui Valley, is at least partially characterized by anomalous changes in SSTs. From a categorical perspective, the statistical model is most skillful in predicting above-normal streamflow years (hit score: $82 \%$; Table 3); categorical outcomes for near- and below-normal streamflow years were less successful (hit scores: 36 and $64 \%$, respectively). The large disparity between above-, near-, and belownormal categorical outcomes may be explained by evaluating cross-validated global spatial correlation maps $\left(1^{\circ} \times 1^{\circ}\right)$ of ONDJ streamflow with the MJJA MEI, following Zimmerman et al. (2016). The spatial correlation plots (1950-2015; Fig. 7) illustrate that years with positive MEI generally correspond with El Niño events and above-normal streamflow conditions, while years with negative MEI generally correspond with La Niña events and below-normal conditions. This produces a strong positive correlation $(0.65)$ between streamflow and SST in the Niño 3.4 region during years with positive MEI and a moderate positive correlation (0.29) during years with negative MEI in the equatorial Pacific Ocean but slightly outside the common ENSO index regions. Correlation mapping between all years and streamflow produces a moderate correlation (0.35) in the common ENSO region, suggesting that El Niño years likely dominate this relationship. However, ENSO is nonlinear, and the amount of moisture transported to the basin during El Niño or La Niña years 
Table 2. Stat-PCR and Stat-Dyn forecast model performance metrics.

\begin{tabular}{|c|c|c|c|c|c|c|c|c|c|c|}
\hline \multicolumn{2}{|l|}{ Forecast } & \multicolumn{3}{|c|}{ Retained predictors } & \multirow{2}{*}{$\begin{array}{l}\text { PC1 } \\
89 \%\end{array}$} & \multirow{2}{*}{$\begin{array}{r}\mathrm{PC} 2 \\
\\
-\end{array}$} & \multirow{2}{*}{$\begin{array}{r}\begin{array}{r}\text { Pearson's } \\
\text { correlation } \\
\text { coefficient }\end{array} \\
0.88\end{array}$} & \multirow{2}{*}{$\begin{array}{r}\text { Hit } \\
\text { score } \\
61 \%\end{array}$} & \multirow{2}{*}{$\begin{array}{r}\begin{array}{r}\text { Extreme } \\
\text { miss } \\
\text { score }\end{array} \\
11 \%\end{array}$} & \multirow{2}{*}{$\begin{array}{r}\text { RPSS } \\
0.31\end{array}$} \\
\hline Statistical approach & $1 \mathrm{Sep}$ & Aug SM & JA Prcp & Aug 3.4 & & & & & & \\
\hline & $1 \mathrm{Aug}$ & Jul SM & JJ Prcp & Jul 3.4 & $63 \%$ & $24 \%$ & 0.63 & $50 \%$ & $12 \%$ & 0.02 \\
\hline & $1 \mathrm{Jul}$ & Jun SM & MJ Prcp & Jun 3.4 & $44 \%$ & $38 \%$ & 0.49 & $31 \%$ & $24 \%$ & -0.39 \\
\hline \multirow[t]{3}{*}{ Dynamical approach } & 1 Jun & JJA 1.2 & JJA Prcp & - & $65 \%$ & $35 \%$ & 0.45 & $26 \%$ & $50 \%$ & -0.32 \\
\hline & 1 May & JJA 3.4 & JJA Prcp & - & $58 \%$ & $42 \%$ & 0.41 & $21 \%$ & $53 \%$ & -0.41 \\
\hline & $1 \mathrm{Jan}$ & JJA 3.4 & - & - & - & - & 0.38 & $20 \%$ & $57 \%$ & -0.76 \\
\hline
\end{tabular}

Table 3. September Stat-PCR model categorical streamflow results: observed vs. forecast.

\begin{tabular}{lrrrr}
\hline & \multicolumn{3}{c}{ Forecast - Sep } \\
\cline { 2 - 5 } & & B & N & A \\
\hline Observed & B & 14 & 3 & 5 \\
& N & 6 & 8 & 8 \\
& A & 2 & 2 & 18 \\
\hline $\begin{array}{l}\text { Below normal (B); near normal (n); above } \\
\text { normal (A). }\end{array}$ & & &
\end{tabular}

will vary dependent upon strength (Meehl et al., 2001) and other factors, as previously discussed and illustrated in Fig. 4.

\subsection{ENSO phase and strength streamflow prediction models}

To evaluate ENSO phase-specific models, the Stat-P\&S approach is adopted. While several forecast leads and Niño 3.4 index windows were evaluated, the Stat-P\&S model performs best for a 1 May forecast, when SSTs in the Niño 3.4 region are at least moderate in strength for a given phase $\left(\geq+0.75^{\circ} \mathrm{C}\right.$ (El Niño) or $\leq-0.75^{\circ} \mathrm{C}$ (La Niña)) or relatively neutral (within $\pm 0.5^{\circ} \mathrm{C}$ departure from the long-term mean) for at least 1 month during January-April (JFMA; Table 4). For 1950-2015, $60 \%$ of years qualify, triggering the 1 May Stat-P\&S categorical prediction model. For moderate conditions (positive and negative), this produces categorical hit scores of $75 \%$ for above normal (El Niño) and $58 \%$ for below normal (La Niña). For moderate La Niña only conditions, 7 of the 10 lowest ONDJ streamflow years on record are captured. The remaining three years of lowest ONDJ streamflow $(1969,1995,2010)$ are predicted as above normal by the Stat-P\&S model due to JFMA Niño 3.4 SSTs greater than $1.0^{\circ} \mathrm{C}$ (strong El Niño conditions).

\subsection{Coupled statistical prediction models}

The Stat-P\&S and Stat-PCR models each provide skillful forecasts at different leads. While Stat-P\&S performs best for a 1 May forecast lead, particularly for predicting high
Table 4. Stat-P\&S model categorical streamflow results: observed vs. forecast.

\begin{tabular}{rrrrrr}
\hline & \multicolumn{5}{c}{ Forecast - May } \\
\hline \multirow{4}{*}{ Observed } & B & B & N & A & DNF \\
& N & 6 & 8 & 5 & 27 \\
& A & 2 & 2 & 18 & \\
\hline
\end{tabular}

Model does not forecast (DNF).

and low ONDJ streamflow, forecasts are issued only categorically; deterministic predictions from the Stat-PCR and Stat-Dyn models at this lead are relatively weak. That is, the Stat-P\&S model relinquishes forecast determinism and in turn increases forecast lead in comparison to the Stat-PCR and Stat-Dyn approaches. The Stat-P\&S model is also triggered for only $60 \%$ of the period of record. The other $40 \%$ of years occur when Niño 3.4 SSTs, for at least 1 month during JFMA, are $\left[+0.5^{\circ} \mathrm{C},+0.75^{\circ} \mathrm{C}\right]$ or $\left[-0.5^{\circ} \mathrm{C},-0.75^{\circ} \mathrm{C}\right]$. These ranges are transitional and do not provide skillful categorical forecasts for the 1 May lead. For this reason, the coupled statistical prediction model defers prediction in these years to 1 September, when the Stat-PCR model is skillful in producing deterministic forecasts of ONDJ streamflow.

To address the limitations of both the Stat-PCR and StatP\&S models, a coupled, sequential forecast approach is adopted which utilizes both the Stat-P\&S and Stat-PCR models in the following manner:

Step 1 The Stat-P\&S model issues a 1 May categorical forecast of ONDJ streamflow when the Niño 3.4 conditions are met. Otherwise, no forecast is issued.

Step 2a If the Stat-P\&S model issued a 1 May forecast, the Stat-PCR model re-evaluates this prediction on the 1 September forecast, updating as necessary, and provides a deterministic forecast.

Step 2b If the Stat-P\&S model did not issue a 1 May forecast, the Stat-PCR model produces a deterministic forecast on 1 September. 
(a)

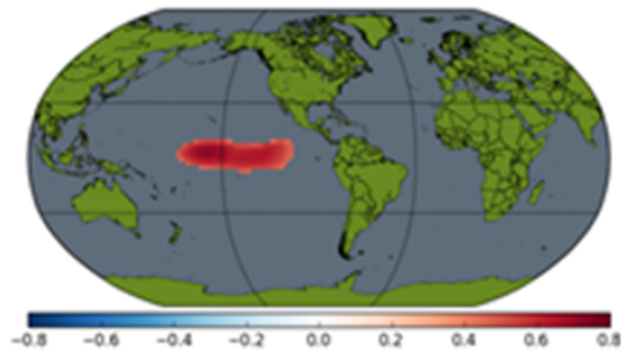

(c)

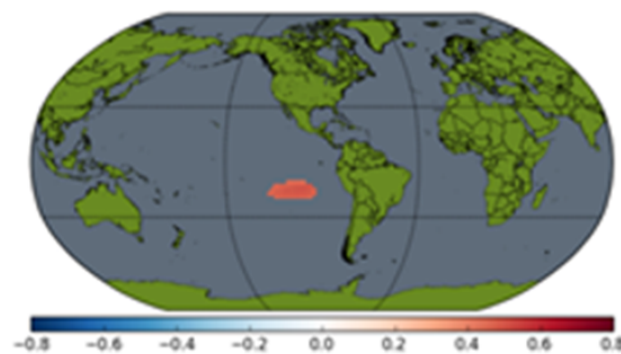

(b)

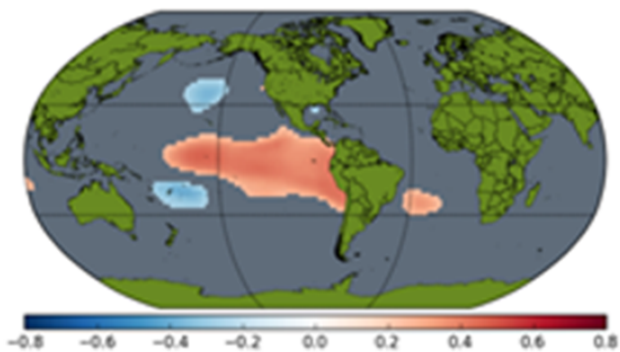

Figure 7. May-August global multivariate ENSO index (MEI) correlated with October-January streamflow at Algarrobal for (a) positive MEI years, (b) all MEI years, and (c) negative MEI years.

For performance evaluation, a categorical hit by Stat-P\&S model becomes a miss if the Stat-PCR model predicts a different (and wrong) category. The Stat-PCR model may also correct a categorical miss by the Stat-P\&S model. The 1 May Stat-P\&S and 1 September Stat-PCR coupled forecast model reveals a large degree of categorical forecast consistency (change between Tables 3 and 4). The Stat-PCR model only predicts a different category than the Stat-P\&S model in 2 of the 39 years evaluated, and for these two cases, it changes extreme misses (least desirable outcome) to hits. One such change was for the year 1995, one of the three lowest years of ONDJ streamflow not correctly categorized by the Stat-P\&S model (initially predicted above-normal while below-normal streamflow was observed). Thus, the coupling of these two statistical models appears to perform superiorly as compared to models individually by skillfully increasing the prediction lead time and allowing for prediction updating, as necessary.

\subsection{Allocation prediction model}

A streamflow prediction-reservoir water balance model system is used to evaluate the performance of water right allocations, as compared with using streamflow observations and streamflow climatology, for a 1 September issuance. Utilizing streamflow observations is synonymous with a perfect forecast. The system is tested in hindcast mode using streamflow median and 80th percentile streamflow predic- tion scenarios of ONDJ streamflow separately. Both the median and 80th percentile approaches outperform climatology, achieving hit scores of $53 \%$, as compared with only a $30 \%$ hit score using climatology (Table 5). Additionally, the climatological median fails to predict any years with extreme reductions $\left(<0.25 \mathrm{~L} \mathrm{~s}^{-1}\right)$; the climatology-based approach over-allocates in $55 \%$ of years, as opposed to only $27 \%$ of years when applying the 80th percentile forecast approach. This is noteworthy from a management perspective, as over-allocation is often considered more problematic than under-allocation from a long-term, drought-focused perspective. The distributions of forecast-based allocations also more closely match observations than climatology, with the median and the 80th percentile forecast scenarios exceeding observation-based allocations by only 0.06 and $0.04 \mathrm{~L} \mathrm{~s}^{-1}$, respectively, on average (Fig. 8a) Over-allocation using climatological streamflow is again evident, as the interquartile range (IQR) of climatological allocations does not align with observations. While the IQR of the forecast-based scenario is larger than that of the observation-based scenario, it does not systematically over-allocate (Fig. 8a). This can also be illustrated by calculating the ratio of each approach (climatology and forecasts) to observed allocations (Fig. 8b). In this case, a perfect score would be a consistent value of 1 , as a climatological or forecast allocation would match each observation-based allocation. The forecast-based allocation ratios produce smaller IQRs and lower median values than climatology-based allocations, implying that the forecasts 
Table 5. Categorical water right allocation results: observed vs. forecast.

\begin{tabular}{|c|c|c|c|c|}
\hline \multirow{2}{*}{\multicolumn{2}{|c|}{$\begin{array}{c}\text { Median forecast } \\
\text { Hit score } 53 \% \\
\text { Extreme miss } 5 \%\end{array}$}} & \multicolumn{3}{|c|}{ Forecast - Sep } \\
\hline & & $\begin{array}{r}\text { Extreme } \\
<0.25 \mathrm{~L} \mathrm{~s}^{-1}\end{array}$ & $\begin{array}{r}\text { Severe } \\
\leq 0.5 \mathrm{~L} \mathrm{~s}^{-1}\end{array}$ & $\begin{array}{r}\text { Moderate } \\
\geq 0.5 \mathrm{~L} \mathrm{~s}^{-1}\end{array}$ \\
\hline \multirow{3}{*}{ Observed } & Extreme & 10 & 11 & 1 \\
\hline & Severe & 5 & 8 & 9 \\
\hline & Moderate & 2 & 3 & 17 \\
\hline \multicolumn{2}{|c|}{ 80th percentile forecast } & \multicolumn{3}{|c|}{ Forecast - Sep } \\
\hline \multirow{2}{*}{\multicolumn{2}{|c|}{$\begin{array}{c}\text { Hit score } 53 \% \\
\text { Extreme miss } 5 \%\end{array}$}} & Extreme & Severe & Moderate \\
\hline & & $<0.25 \mathrm{~L} \mathrm{~s}^{-1}$ & $\leq 0.5 \mathrm{~L} \mathrm{~s}^{-1}$ & $\geq 0.5 \mathrm{Ls}^{-1}$ \\
\hline \multirow{3}{*}{ Observed } & Extreme & 11 & 11 & 0 \\
\hline & Severe & 6 & 9 & 7 \\
\hline & Moderate & 2 & 5 & 15 \\
\hline \multicolumn{2}{|c|}{ Climatology } & \multicolumn{3}{|c|}{ Forecast - Sep } \\
\hline \multirow{2}{*}{\multicolumn{2}{|c|}{$\begin{array}{c}\text { Hit score } 30 \% \\
\text { Extreme miss } 2 \%\end{array}$}} & Extreme & Severe & Moderate \\
\hline & & $<0.25 \mathrm{~L} \mathrm{~s}^{-1}$ & $\leq 0.5 \mathrm{~L} \mathrm{~s}^{-1}$ & $\geq 0.5 \mathrm{~L} \mathrm{~s}^{-1}$ \\
\hline \multirow{3}{*}{ Observed } & Extreme & 0 & 21 & 1 \\
\hline & Severe & 0 & 9 & 13 \\
\hline & Moderate & 0 & 11 & 11 \\
\hline
\end{tabular}
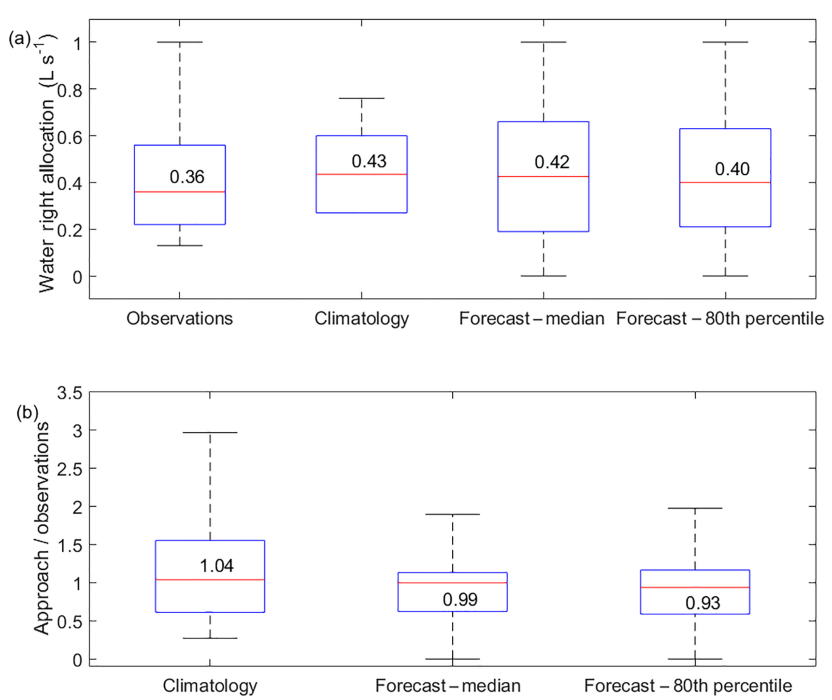

Figure 8. Reservoir model-derived forecast allocations: (a) absolute allocation values and (b) ratio of forecast allocations to observed allocations.

are better aligned with observations and slightly more conservative.

The probabilistic modeling approach also allows for an understanding of categorical forecast certainty and strength, that is, the degree to which the model suggests a category (Fig. 9). In this case, the forecast-based allocations more often indicate a stronger forecast tendency (higher probability) toward one category, whereas the climatology-based allocations often indicate a weaker tendency to shift. While this is not always the case, from a reservoir management perspec- tive, climatology-based allocations provide less actionable information, as the strength of the predicted categories is often not too dissimilar, even in years where correct predictions are made. In contrast, for the 28 years where forecast-based allocations of a category exceed $80 \%$ (a strong prediction), the hit score is $79 \%$, a high success rate, and further, no extreme misses occur (moderate category predicted, extreme category observed), avoiding over-allocation in dry years.

The effect of over- and under-allocation by both forecastand climatology-based approaches on end-of-year reservoir storage is also evaluated. Large deviations from the $100 \mathrm{mil}-$ lion $\mathrm{m}^{3}$ target volume (1 February) are viewed as problematic for the JVRE and water rights holders (Fig. 10). The prior analysis demonstrates the propensity for the climatology-based approach to consistently over-allocate, resulting in reservoir volumes consistently below the target. The forecast-based scenarios have a smaller IQR with median values approaching the target value. The climatologybased approach also allocates the full reservoir volume in $33 \%$ of years (leaving the reservoir empty), which happens in only $11 \%$ of years under the forecast-based scenarios, due to prediction error (Fig. 10).

\section{Discussion}

The framework developed here, although applied specifically to the Elqui Valley in Chile, can provide a broad pathway for managers and rights holders in water rights managed basins to benefit from streamflow forecast-informed reservoir allocations. Although streamflow predictions hold modest skill for the Elqui, the coupling of the StatP\&S and Stat-PCR models, and subsequent coupling of forecasts with the human-managed allocation framework, provides for increases in system efficiency as compared with climatology-based forecasts. Specifically, the Stat-PCR streamflow prediction-reservoir water balance model system produces values closely matched with observations over the historical period, and each forecast (median, 80th percentile) outperforms climatology. Use of the 80th percentile StatPCR forecast is intended to represent risk aversion; however, the probabilistic framework allows assessment for any risk preference. Ensemble predictions illustrate the general propensity of a climatology-based allocation to provide limited actionable information in contrast to forecast-based allocations, which exhibit enhanced skill when the model issues strong predictions (> $80 \%$ categorical likelihood). However, in years when the Stat-PCR forecast-based allocation model issues a weak prediction (no dominant tendency toward any specific category) other allocation decision frameworks may be worth investigating (e.g., allocation based on existing storage only as a hedge against inflow uncertainty). The development and implementation of the probabilistic framework by reservoir managers, as a mechanism to convert streamflow forecasts into forecast allocations, may arguably necessitate 

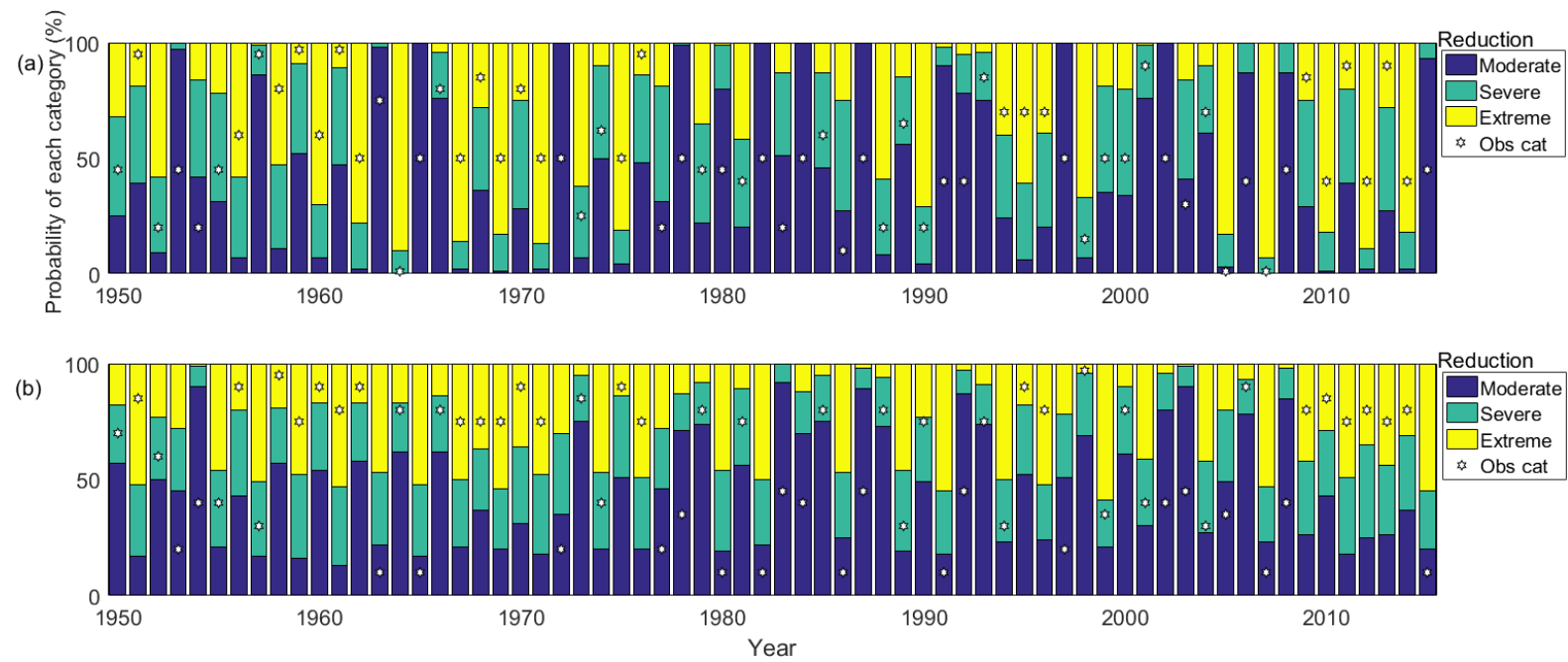

Figure 9. Probabilistic water right allocation forecast using (a) 1 September PCR-Stat model 80th percentile and (b) long-term averages (climatology).

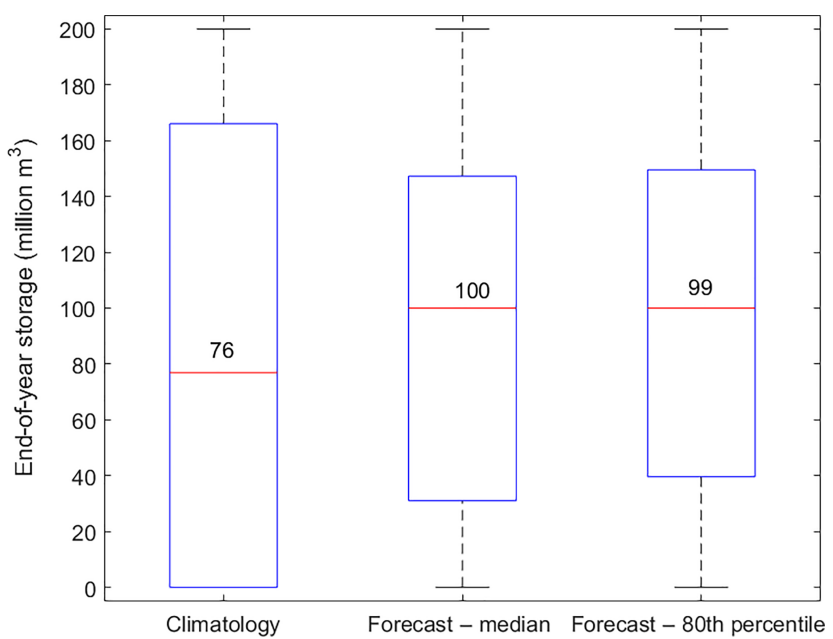

Figure 10. End-of-year reservoir storage under three allocation approaches; $100 \mathrm{Mm}^{3}$ is the target.

a higher level of communication with water rights holders. Probabilistic forecasts can provide the option value to water rights holders if the strength of the category predicted would alter water rights holders' decisions (e.g., change cropping decisions, prompt water procurement or sales) acting under the presumption of economic rationality. This hypothesis may also be worth investigating.

Selection of categorical thresholds (three for this case study) is based on equal distribution of observations and does not necessarily represent the preferences of reservoir managers or rights holders; however, these thresholds are easily adjustable. For example, if only two categories are selected as allocations above and below $0.75 \mathrm{~L} \mathrm{~s}^{-1}$, the hit score rises to $92 \%$, which could be representative of some productiv- ity threshold (e.g., crop water requirement). The framework is thus sufficiently flexible to allow managers to select categories which reflect true differences in the utility of allocations to water rights holders.

While the approaches in this research are predominantly a demonstration of concept, the model framework is consistent with the current operations of Puclaro reservoir. However, it is not optimized to hedge against expected future (multi-year) conditions. While the model may be informative over the long term, resulting in allocation and storage values better matched with observations than climatologybased allocations, it performs poorly in certain years, most notably during the 2009-2015 hydrologic and meteorological drought (Fig. 9a). While poor model performance during this period is undoubtedly due in part to the limited reservoir operating rules, the Stat-PCR approach tends to underpredict extremes, especially when they occur consecutively. Further forecast model development will focus on improving predictive skill of extreme events, particularly dry periods, making use of non-parametric methods and additional multi-model approaches, and dynamic rule structures and simulation techniques. Even so, adoption of the approaches presented here by water managers and rights holders bodes well for improved economic efficiency and benefits across the Elqui Valley.

\section{Conclusions}

The focus of this research is to develop an understanding of the mechanisms contributing to austral summer streamflow in the Elqui Valley, investigate model skill at varied forecast leads, and produce forecast-based water right allocations to inform water resources management decision-making. Like many regions, the dynamic nature of ocean, atmosphere, and 
terrestrial interactions, which contribute to moisture transport in the Elqui Valley, is undoubtedly complex and challenges hydrologic prediction models at increasing leads. The mixed success of streamflow forecasts currently in use for the Elqui reflects this. Here, a framework is established by which streamflow forecasts can be produced and coupled with human-managed allocation systems to promote equity and efficiency in the use of limited water resources.

Correlation and composite mapping suggest moisture transport to the Elqui Valley is dependent on the phase, strength, and timing of many variables (Fig. 4). While austral winter precipitation, SST, and soil moisture correlations with ONDJ streamflow at varied leads are encouraging (Fig. 5), the Stat-PCR approach, which makes use of these predictors, is skillful only at a 1 September lead, as indicated by RPSS scores and other forecast validation metrics (Table 2). The Stat-Dyn approach, using precipitation and SSTs, results in inferior outcomes compared with the Stat-PCR model. The Stat-P\&S model, however, provides skillful predictions of ONDJ streamflow at a 1 May lead, albeit categorically, and is triggered in only $60 \%$ of the period 1950-2015.

The broader insight gained is in the coupling of the StatP\&S and Stat-PCR models to produce initial (1 May) and updated (1 September) forecasts which may be valuable to both reservoir managers and water rights holders. From a reservoir management perspective, properly setting the per right water allocation (1 September) is critically important to satisfy rights holders and maintain adequate reservoir storage for the uncertain future. The Stat-PCR component of the coupled model provides skill superior to climatology and likely better informs allocation decisions. Reservoir managers, however, are also expected to provide a non-binding 1 May allocation forecast, allowing rights holders, specifically farmers with crop choice flexibility and/or water right leasing potential, to supplement through the water market as necessary. The Stat-P\&S categorical forecast with a 1 May lead can inform these longer planning actions. The strong categorical consistency between the 1 May Stat-P\&S and 1 September Stat-PCR forecasts may also serve to reinforce confidence in the forecast outcomes; the two models only differ in prediction categories twice in the 66 years evaluated. The conclusion here is that coupled forecasts need not be strictly deterministic, and using early categorical forecasts to provide an indication of expected conditions, and reinforcing the prediction with a revised deterministic forecast as more observations of local variables (e.g., precipitation) become available, may be useful for water rights holders. In addition, linking the streamflow forecast with the human managed allocation system is broadly relevant as a mechanism to promote efficiency in the use of limited water resources. The framework presented here addresses the unique set of circumstances in water-rights-managed basins and represents an advancement in linking season-ahead streamflow forecasts to water resources systems.
Code availability. Should future reproduction of results become necessary, any codes will be made available, by the corresponding author, upon request.

Data availability. The data used to produce this research come from open sources, including the Chilean Ministry of Public Works - Dirrecion de Aguas (DGA) and the National Oceanic and Atmospheric Administration. Through use of the International Research Institute's data library, all relevant datasets may be obtained.

Author contributions. JD, ECGO, and PB each contributed to the hydroclimatological analysis, developed model code, and evaluated simulations.

Competing interests. The authors declare that they have no conflict of interest.

Special issue statement. This article is part of the special issue "Sub-seasonal to seasonal hydrological forecasting". It is a result of the HEPEX workshop on seasonal hydrological forecasting, Norrköping, Sweden, 21-23 September 2015.

Acknowledgements. This work is partially funded by a scholarship provided by the Air Force Institute of Technology.

Edited by: Fredrik Wetterhall

Reviewed by: Ángel G. Muñoz and one anonymous referee

\section{References}

Aceituno, P.: On the Functioning of the Southern Oscillation in the South American Sector. Part I: Surface Climate, Mon. Weather Rev., 116, 505-524, 1988.

Balmaseda, M. A., Davey, M. K., and Anderson, D. L. T.: Decadal and Seasonal Dependence of ENSO Prediction Skill, J. Climate, 8, 2705-2715. 1995.

Barnston, A. G., van den Dool, H. M., Rodenhuis, D. R., Ropelewski, C. R., Kousky, V. E., O’Lenic, E. A., Livezey, R. E., Zebiak, S. E., Cane, M. A., Barnett, T. P., Graham, N. E., Ji, M., and Leetmaa, A.: Long-Lead Seasonal Forecasts - Where Do We Stand?, B. Am. Meteorol. Soc., 75, 2097-2114, 1994.

Barsugli, J. J., Vogel, J. M., Kaatz, L., Smith, J. B., Waage, M., and Anderson, C. J.: Two Faces of Uncertainty: Climate Science and Water Utility Planning Methods, J. Water Res. Pl.-ASCE, 138, 389-395, 2012.

Block, P.: Tailoring seasonal climate forecasts for hydropower operations, Hydrol. Earth Syst. Sci., 15, 1355-1368, https://doi.org/10.5194/hess-15-1355-2011, 2011.

Block, P. and Rajagopalan, B.: Interannual Variability and Ensemble Forecast of Upper Blue Nile Basin Kiremt Season Precipitation, J. Hydrometeorol., 8, 327-343, 2007. 
Block, P. J., Souza Filho, F. A., Sun, L., and Kwon, H.-H.: A Streamflow Forecasting Framework using Multiple Climate and Hydrological Models1, JAWRA J. Am. Water Resour. As., 45, 828-843, 2009.

Bosilovich, M. G., Chen, J., Robertson, F. R., and Adler, R. F.: Evaluation of Global Precipitation in Reanalyses, J. Appl. Meteorol. Clim., 47, 2279-2299, 2008.

Brown, C. and Lall, U.: Water and economic development: The role of variability and a framework for resilience, Nat. Resour. Forum, 30, 306-317, 2006.

Cepeda, J. and Lopez-Cortes, F.: Sistemas Naturales de La Hoya Hidrografica del Rio Elqui: Variabilidad Climatica a Vulnerabilidad, 2004.

Chambers, J. C., Mullick, S. K., and Smith, D. D.: How to Choose the Right Forecasting Technique, Harvard Business Review, Harvard University, Graduate School of Business Administration, 71403, 1971.

Christensen, N. S., Wood, A. W., Voisin, N., Lettenmaier, D. P., and Palmer, R. N.: The Effects of Climate Change on the Hydrology and Water Resources of the Colorado River Basin, Clim. Change, 62, 337-363, 2004.

Dee, D. P., Uppala, S. M., Simmons, A. J., Berrisford, P., Poli, P., Kobayashi, S., Andrae, U., Balmaseda, M. A., Balsamo, G., Bauer, P., Bechtold, P., Belijaars, A. C. M., van de Berg, L., Bidlot, J., Bormann, N., Delsol, C., Dragani, R., Fuentes, M., Geer, A. J., Haimberger, L., Healy, S. B., Hersbach, H., Holm, E. V., Isaksen, L., Kallberg, P., Kohler, M., Matricardi, M., McNally, A. P., Monge-Sanz, B. M., Morcrette, J. J., Park, B. K., Peubey, C., de Rosnay, P., Tavolato, C., Thepaut, J. N., and Vitart, F.: The ERA-Interim reanalysis: configuration and performance of the data assimilation system, Q. J. Roy. Meteor. Soc., 137, 553-597, 2011.

Donoso, G.: Water markets: case study of Chile's 1981 Water Code, Cien. Inv. Agr., 33, 157-171, 2006.

Falvey, M. and Garreaud, R.: Wintertime Precipitation Episodes in Central Chile: Associated Meteorological Conditions and Orographic Influences, J. Hydrometeorol., 8, 171-193, 2007.

Fowler, H. J. and Ekström, M.: Multi-model ensemble estimates of climate change impacts on UK seasonal precipitation extremes, Int. J. Climatol., 29, 385-416, 2009.

Garreaud, R. D., Vuille, M., Compagnucci, R., and Marengo, J.: Present-day South American climate, Palaeogeogr. Palaeocl., 281, 180-195, 2009.

Hamlet, A. F., Huppert, D., and Lettenmaier, D. P.: Economic Value of Long-Lead Streamflow Forecasts for Columbia River Hydropower, J. Water Res. Pl.-ASCE, 128, 91-101, 2002.

Hansen, J. W., Potgieter, A., and Tippett, M. K.: Using a general circulation model to forecast regional wheat yields in northeast Australia, Agr. Forest Meteorol., 127, 77-92, 2004.

Hearne, R. R. and Easter, K. W.: Water Allocation and Water Markets: An Analysis of Gains-from-trade in Chile, World Bank Publications, Washington D.C., 1995.

Helmuth, M. E., Moorhead, A., Thomson, M. C., and Williams, J.: Climate Risk Management in Africa: Learning from practice, International Research Institute for Climate and Society, The Earth Institute at Columbia University, Palisades, New York, 2007.

Huang, J., van den Dool, H. M., and Georgarakos, K. P.: Analysis of Model-Calculated Soil Moisture over the United States (1931-
1993) and Applications to Long-Range Temperature Forecasts, J. Climate, 9, 1350-1362, 1996.

Kalnay, E., Kanamitsu, M., Kistler, R., Collins, W., Deaven, D., Gandin, L., Iredell, M., Saha, S., White, G., Woollen, J., Zhu, Y., Leetmaa, A., Reynolds, R., Chelliah, M., Ebisuzaki, W., Higgins, W., Janowiak, J., Mo, K. C., Ropelewski, C., Wang, J., Jenne, R., and Joseph, D.: The NCEP/NCAR 40-Year Reanalysis Project, B. Am. Meteorol. Soc., 77, 437-471, 1996.

Kalthoff, N., Bischoff-Gauß, I., Fiebig-Wittmaack, M., Fiedler, F., Thürauf, J., Novoa, E., Pizarro, C., Castillo, R., Gallardo, L., Rondanelli, R., and Kohler, M.: Mesoscale Wind Regimes in Chile at 30 S, J. Appl. Meteorol., 41, 953-970, 2002.

Kalthoff, N., Fiebig-Wittmaack, M., Meissner, C., Kohler, M., Uriarte, M., Bischoff-Gauss, I., and Gonzales, E.: The energy balance, evapo-transpiration and nocturnal dew deposition of an arid valley in the Andes, J. Arid Environ., 65, 420-443, 2006.

Kendon, E. J., Roberts, N. M., Fowler, H. J., Roberts, M. J., Chan, S. C., and Senior, C. A.: Heavier summer downpours with climate change revealed by weather forecast resolution model, Nat. Clim. Change, 4, 570-576, 2014.

Kirtman, B. P., Dughong Min, J. M. Infanti, Kinter, J. L., Paolino, D. A., Zhang, Q., van den Dool, H., Saha, S., Mendez, M. P., Becker, E., Peng, P., Tripp, P., Huang, J., DeWitt, D. G., Tippett, M. K., Barnston, A. G., Li, S., Rosati, A., Schubert, S. D., Rienecker, M., Suarez, M., Li, Z. E., Marshak, J., Lim, Y. K., Tribbia, J., Pegion, K., Merryfield, W. J., Densi, B., and Wood, E. F.: The North American Multimodel Ensemble: Phase1 Seasonal-to-Interannual Prediction; Phase-2 toward Developing Intraseasonal Prediction, B. Am. Meteorol. Soc., 95, 585601, https://doi.org/10.1175/BAMS-D-12-00050.1, 2013.

Lins, H. F.: Interannual streamflow variability in the United States based on principal components, Water Resour. Res., 21, 691701, 1985.

Maraun, D.: Bias Correction, Quantile Mapping, and Downscaling: Revisiting the Inflation Issue, J. Climate, 26, 2137-2143, 2013.

Mason, D. S. J. and Stephenson, D. B.: How Do We Know Whether Seasonal Climate Forecasts are Any Good? In Seasonal Climate: Forecasting and Managing Risk, edited by: Troccoli, D. A., Harrison, D. M., Anderson, P. D. L. T., and Mason, D. S. J., Springer, the Netherlands, 259-289, 2008.

Meehl, G. A., Gent, P. R., Arblaster, J. M., Otto-Bliesner, B. L., Brady, E. C., and Craig, A.: Factors that affect the amplitude of El Nino in global coupled climate models, Clim. Dynam., 17, 515-526, 2001.

Montecinos, A. and Aceituno, P.: Seasonality of the ENSO-Related Rainfall Variability in Central Chile and Associated Circulation Anomalies, J. Climate, 16, 281-296, 2003.

Narula, K. K. and Lall, U.: Challenges in Securing India's Water Future, J. Crop Improv., 24, 85-91, 2009.

Olmstead, S. M.: The Economics of Managing Scarce Water Resources, Rev. Environ. Econ. Policy, 4, 179-198, 2010.

Regonda, S. K., Rajagopalan, B., and Clark, M.: A new method to produce categorical streamflow forecasts, Water Resour. Res., 42, W09501, https://doi.org/10.1029/2006WR004984, 2006.

Robertson, A. W., Baethgen, W., Block, P., Lall, U., Sankarasubramanian, A., de Assis de Souza Filho, F., and Verbist, K. M. J.: Climate risk management for water in semi-arid regions, Earth Perspect., 1, 12, https://doi.org/10.1186/2194-6434-1-12, 2014. 
Saha, S., Moorthi, S., Wu, X., Wang, J., Nadiga, S., Tripp, P., Behringer, D., Hou, Y.-T., Chuang, H., Iredell, M., Ek, M., Meng, J., Yang, R., Mendez, M. P., van den Dool, H., Zhang, Q., Wang, W., Chen, M., and Becker, E.: The NCEP Climate Forecast System Version 2, J. Climate, 27, 2185-2208, 2013.

Sankarasubramanian, A., Lall, U., Souza Filho, F. A., and Sharma, A.: Improved water allocation utilizing probabilistic climate forecasts: Short-term water contracts in a risk management framework, Water Resour. Res., 45, W11409, https://doi.org/10.1029/2009WR007821, 2009.

Santibañez, F., Romero, A. H., Peña, T. H., Gwynne, R., Ihl, M., and Riva, A.: Climate Change and Regional Development in the Norte Chico, Government of Chile - Environmental Change Unit, Research Report No. 10, 1992.

Saunders, M. A. and Fletcher, C.: Verification of Spring 2004 UK city temperature seasonal forecasts, London's Global University, 2004.

Souza Filho, F. A. and Lall, U.: Seasonal to interannual ensemble streamflow forecasts for Ceara, Brazil: Applications of a multivariate, semiparametric algorithm, Water Resour. Res., 39, 1307, https://doi.org/10.1029/2002WR001373, 2003.

Stakhiv, E. Z.: Policy implications of climate change impacts on water resources management, Water Policy, 1, 159-175, 1998.

Svoboda, M., LeComte, D., Hayes, M., Heim, R., Gleason, K., Angel, J., Rippey, B., Tinker, R., Palecki, M., Stooksbury, D., Miskus, D., and Stephens, S.: The drought monitor, B. Am. Meteorol. Soc. Boston, 83, 1181-1190, 2002.

Tanaka, S. K., Zhu, T., Lund, J. R., Howitt, R. E., Jenkins, M. W., Pulido, M. A., Tauber, M., Ritzema, R. S., and Ferreira, I. C.: Climate Warming and Water Management Adaptation for California, Clim. Change, 76, 361-387, 2006.

Trenberth, K. E., Caron, J. M., Stepaniak, D. P., and Worley, S.: Evolution of El Nio-Southern Oscillation and Global Atmospheric Surface Temperatures, J. Geophys. Res.-Atmos., 107, AAC 5-1-AAC 5-17, https://doi.org/10.1029/2000JD000298, 2002.
Verbist, K., Robertson, A. W., Cornelis, W. M., and Gabriels, D.: Seasonal Predictability of Daily Rainfall Characteristics in Central Northern Chile for Dry-Land Management, J. Appl. Meteorol. Clim., 49, 1938-1955, 2010.

Webster, P. J. and Hoyos, C. D.: Beyond the spring barrier?, Nat. Geosci., 3, 152-153, 2010

Wheeler, S., Garrick, D., Loch, A., and Bjornlund, H.: Evaluating water market products to acquire water for the environment in Australia, Land Use Policy, 30, 427-436, 2013.

Wolter, K. and Timlin, M. S.: Monitoring ENSO in COADS with a seasonally adjusted principal component index, Proc. of the 17th Climate Diagnostics Workshop, Vol. 5257, 1993.

Wolter, K. and Timlin, M. S.: Measuring the strength of ENSO events: How does 1997/98 rank?, Weather, 53, 315-324, 1998.

You, J.-Y. and Cai, X.: Determining forecast and decision horizons for reservoir operations under hedging policies, Water Resour. Res., 44, W11430, https://doi.org/10.1029/2008WR006978, 2008.

Young, G., Zavala, H., Wandel, J., Smit, B., Salas, S., Jimenez, E., Fiebig, M., Espinoza, R., Diaz, H., and Cepeda, J.: Vulnerability and adaptation in a dryland community of the Elqui Valley, Chile. Clim. Change, 98, 245-276, 2009.

Zimmerman, B. G., Vimont, D. J., and Block, P. J.: Utilizing the state of ENSO as a means for season-ahead predictor selection, Water Resour. Res., 52, 3761-3774, 2016.

Zwick, W. R. and Velicer, W. F.: Comparison of five rules for determining the number of components to retain, Psychol. Bull., 99 432-442, 1986 